\title{
Zastosowanie zgrzewania wybuchowego do wytwarzania kompozytów metalowych z osnową aluminiową
}

\author{
Application of explosion welding for fabrication \\ of aluminum matrix metal composites
}

\section{Streszczenie}

Energia wybuchu może zostać wykorzystana do realizacji wielu procesów technologicznych, m.in. wytwarzania złączy zgrzewanych, prasowania proszków, tłoczenia, odprężania i utwardzania metali. Bardzo interesującym zastosowaniem technologii zgrzewania wybuchowego jest wytwarzanie kompozytów metalowych. W artykule scharakteryzowano kompozyty metalowe i zgrzewanie wybuchowe jako jedną z metod ich otrzymywania. Przedstawiono autorską technologię uzyskiwania kompozytów metalowych z osnowią aluminiową wzmocnionych wysokostopowymi drutami stalowymi. $\mathrm{Na}$ podstawie wyników badań metalograficznych, wytrzymałościowych oraz analitycznych wykazano przydatność wykorzystania energii wybuchu do wytwarzania kompozytów z aluminium wzmacnianego drutami stalowymi oraz zaproponowano kierunki dalszych badań.

\section{Abstract}

The energy of explosion can be used to implement a number of processes, including manufacturing of explosion welded joints, pressing powders, press forming, annealing and hardening of metals. Highly interesting application for explosion welding technology is the production of metal composites. The article characterizes the metal composites and explosion welding as one of the methods for obtaining them. An original technology of obtaining metal composites with aluminum matrix strengthened with steel wires was presented. Based on the results of metallographic, strength and analytic tests the suitability of the use of energy of explosion to produce composites of aluminum strengthened with steel wires was demonstrated and directions for future research were suggested.

\section{Wstęp}

Postęp m.in. w przemyśle energetycznym, lotniczym, kosmicznym czy samochodowym wymusza opracowywanie nowych materiałów konstrukcyjnych, które muszą charakteryzować się bardzo specyficznymi właściwościami. Bardzo często właściwości te są połączeniem cech charakterystycznych dla różnych

Dr inż. Grzegorz Rogalski, dr inż. Dariusz Fydrych, prof. dr hab. inż. Włodzimierz Walczak - Politechnika Gdańska. materiałów, np. odporności na korozję połączonej $z$ dużą wytrzymałością mechaniczną. Materiałami spełniającymi tak wysokie wymagania są m.in. kompozyty metalowe. Nie należą one jednak do materiałów powszechnie stosowanych ze względu na małą dostępność. Wynika to z bardzo dużych kosztów wytwarzania, na które składają się złożone i kosztowne cykle technologiczne. Badania są prowadzone w kierunku uproszczenia technologii wytwarzania kompozytów metalowych oraz do zastąpienia kosztownych, unikatownych włókien zbrojących włóknami tańszymi, łatwiej dostępnymi, przy równoczesnym zachowaniu wymaganych od kompozytu odpowiednich właściwości mechanicznych i fizycznych. 
Obecnie do wytwarzania kompozytów metalowych najczęściej stosowane są metody, w których wzmocnienie wprowadzane jest mechanicznie. Stosuje się w tym celu procesy obróbki plastycznej, procesy odlewnicze oraz procesy związane ze strącaniem i napylaniem [5]. Metodą, która umożliwia łączenie materiałów metalowych o odmiennych właściwościach fizykochemicznych, jest zgrzewanie wybuchowe. Wykorzystuje się ją również do wytwarzania kompozytów metalowych. Fala wybuchowa zapewnia bowiem uzyskiwanie wymaganych do tego celu dużych nacisków i bardzo krótkich czasów ich działania.

\section{Charakterystyka kompozytów metalowych}

Kompozyty to materiały uzyskiwane przez połączenie ze sobą co najmniej dwóch różnych materiałów inżynierskich, w wyniku którego będą posiadać właściwości będące wypadkową komponentów i ich udziałów objętościowych. Przyjęto, że kompozyt to materiał, który musi spełniać następujące warunki $[4,9]$ :

- Materiał musi być wytworzony sztucznie.

- Materiał musi składać się z co najmniej dwóch różniących się chemicznie i fizycznie materiałów, z których jeden stanowi osnowę, a drugi wzmocnienie.

- Pomiędzy komponentami musi istnieć wyraźna granica rozdziału.

- Zadaniem osnowy jest spajanie wzmocnienia i przekazywanie obciążeń zewnętrznych na wzmocnienie.

- Zadaniem wzmocnienia jest przenoszenie obciążeń zewnętrznych.

Osnowa w materiale kompozytowym poza spajaniem wzmocnienia oraz przenoszeniem obciążenia na włókna chroni je przed czynnikami zewnętrznymi. Właściwości osnowy mają również wpływ na niektóre właściwości kompozytów, np. ciągliwość czy właściwości izolacyjne. Z punktu widzenia wytwarzania kompozytów metalowych najczęściej jako osnowy mają zastosowanie:

- stopy metali lekkich (Al, Mg) - zastosowanie w przemyśle lotniczym i samochodowym;

- stopy srebra i miedzi - zastosowanie tam, gdzie wymagane są dobre właściwości cieplne oraz elektryczne;

- stopy niklu - zastosowanie na łopatki turbin (duża żarowytrzymałość);

- stopy ołowiu i cynku - zastosowanie tam, gdzie wymagane są bardzo dobre właściwości ślizgowe.

Wzmocnienia metaliczne są wytwarzane najczęściej w postaci włókien. Mogą być one ułożone w kompozycie w różny sposób oraz pod różnymi postaciami, np.: włókna ciągłe jednokierunkowe, różnego rodzaju siatki (typu fornir), siatki przestrzenne, siatki płócienne, włókna nieciągłe o ustalonym kierunku oraz włókna nieciągłe rozmieszczone chaotycznie.
Włókna te maja najczęściej średnice ponad $150 \mu \mathrm{m}$ (w zależności od grubości osnowy i wymaganych właściwości). Wytrzymałość wzmocnienia nie przekracza zazwyczaj $R_{m}=1800 \mathrm{MPa}$ [4]. Prowadzone są jednak badania nad otrzymaniem włókien o mniejszych średnicach i większej wytrzymałości na rozciąganie przy małych kosztach ich wytwarzania. Przykładem takiego rozwiązania jest kompozyt o osnowie niklowej i wzmocnieniu wolframowym, będący doskonałym materiałem do pracy w wysokiej temperaturze.

Zastosowanie kompozytów metalowych ma miejsce w sytuacjach, w których wysoki koszt zakupu rekompensowany jest znacznym zwiększeniem żywotności elementów (obniżenie kosztów eksploatacji). Dlatego znalazły one zastosowanie głównie w przemyśle lotniczym oraz energetycznym:

- kompozyt aluminium-bor: łopatki wirnika,

- kompozyt ołów-drut stalowy: łożyska,

- kompozyt miedź-drut wolframowy: dysze silników,

- kompozyt aluminium-stal: rury wysokociśnieniowe.

Jak widać, kompozyty metalowe mają liczne zale-

ty. Wraz z opracowaniem nowych, tańszych technologii wytwarzania kompozytów oraz ich komponentów mogą one znaleźć szerokie zastosowanie w różnych dziedzinach.

\section{Zgrzewanie wybuchowe kompozytów metalowych}

Zgrzewanie wybuchowe to metoda trwałego łączenia dwóch lub więcej elementów przez ich zderzenie z dużymi prędkościami $(300 \div 3000 \mathrm{~m} / \mathrm{s})$ spowodowane detonacją materiału wybuchowego [2, 10]. Najczęściej stosowanym sposobem zgrzewania wybuchowego jest zgrzewanie bezpośrednie, w którym materiał wybuchowy w czasie detonacji działa bezpośrednio na jeden z przedmiotów i dociska go do drugiego. Podstawowe układy zgrzewania przedstawiono na rysunku 1. Możliwe jest również kształtowanie konstrukcji

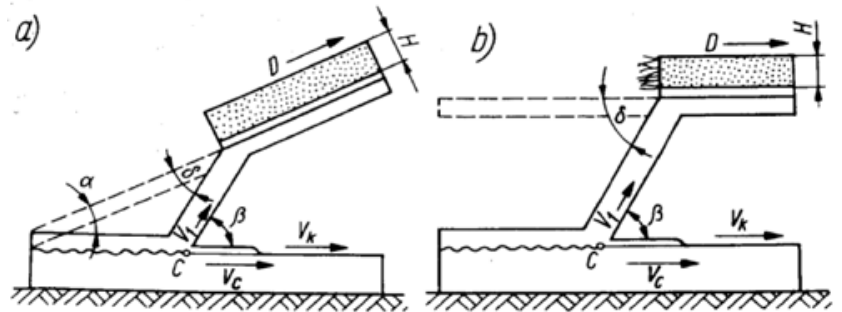

Rys. 1. Schematy przebiegu zderzenia płyt dla podstawowych układów zgrzewania: $\beta$ - kąt zderzenia, $\delta$ - kąt odrzutu, $\alpha$ - kąt wstępnego ustawienia płyt, $V_{1}, V_{c}$ - prędkość punktu zderzenia $C$ względem zgrzewanych płyt, $V_{k}$ - prędkość strumienia odwrotnego, D - prędkość detonacji, $\mathrm{H}$ - wysokość warstwy materiału wybuchowego [9]

Fig. 1. Schemes of a collision of plates for basic explosion welding systems: $\beta$ - the collision angle, $\delta$ - the angle of recoil, $\alpha-$ the presetting plates angle, $V_{1}, V_{C}-$ the collision point velocity $C$ in relation to explosion welded plates, $V_{k}$ - the reverse jet velocity, $\mathrm{D}$ - the detonation velocity, $\mathrm{H}$ - the height of the layer of explosive material 
w czasie zgrzewania [9]. Parametrami charakteryzującymi zgrzewanie wybuchowe są: prędkość zderzenia $V_{p}[\mathrm{~m} / \mathrm{s}]$, kąt zderzenia $\beta\left[^{\circ}\right]$, prędkość łączenia $V$ $[\mathrm{m} / \mathrm{s}]$, prędkość detonacji materiału wybuchowego $V_{d}$ [m/s] oraz kąt wstępnego ustawienia płyt $\alpha\left[^{\circ}\right]$. Bardzo ważnymi czynnikami procesu są właściwości fizyczne i mechaniczne łączonych elementów oraz ich wymiary. Do zgrzewania wykorzystuje się najczęściej dwa układy, tj. układ pod kątem (płyta nastrzeliwana ustawiona jest pod odpowiednim kątem względem płyty podstawowej) oraz układ równoległy (cała powierzchnia płyty nastrzeliwanej znajduje się w stałej odległości od płyty podstawowej). Schematy podstawowych układów zgrzewania wybuchowego pokazano na rysunku 1.

Literatura dotycząca wytwarzania kompozytów metalowych z wykorzystaniem zgrzewania wybuchowego jest nieliczna [3, 6, 10]. Z analizy źródeł literaturowych wynika, że zgrzewanie wybuchowe jest interesującym i alternatywnym sposobem otrzymywania kompozytów metalowych, jednak bardzo ważną rolę spełnia odpowiednie przygotowanie układu do zgrzewania [1]. Należy także pamiętać, że w przypadku kompozytów metalowych połączenia wzmocnienia z osnową narażone są przy zgrzewaniu wybuchowym na powstawanie niekorzystnych warstw pośrednich (związków międzymetalicznych) [10].

Bardziej szczegółowe informacje dotyczą opracowania technologii zgrzewania w układzie skośnym wielowarstwowych kompozytów o osnowie aluminiowej (folia o grubości $190 \mu \mathrm{m}$ ) i tytanowej (folia o grubości $310 \mu \mathrm{m})$ ze wzmocnieniem z drutu stalowego o średnicy $\varphi=200 \mu \mathrm{m}$ i $R_{m}=3,2 \mathrm{GPa}$. Stwierdzono, że wytrzymałość kompozytów wzrasta wraz ze stopniem wypełnienia wzmocnieniem, a istotną rolę odgrywa połączenie na granicy włókno-folia. W przypadku niewłaściwego połączenia wytrzymałość jest niższa niż obliczona na podstawie prawa mieszanin, co potwierdziły badania wzmocnienia [6].

Kompozyty metalowe można otrzymywać również przy zastosowaniu wzmocnienia w postaci blach. Zadowalające rezultaty otrzymano w wyniku jednoczesnego zgrzewania kilku warstw miedzi i mosiądzu, aluminium i stali odpornej na korozję, miedzi i stali odpornej na korozję, aluminium i stali maraging oraz tytanu i stali maraging [3].

Kompozyty metalowe wzmacniane drutami powinny charakteryzować się jak największym stopniem wypełnienia. Zgrzewanie wybuchowe wymaga zatem szczegółowej analizy procesu technologicznego [10].

\section{Badania własne}

Celem badań było opracowanie technologii zgrzewania wybuchowego kompozytów metalowych oraz określenie jakości i właściwości wytrzymałościowych połączenia między komponentami.
Przeprowadzono cztery próby zgrzewania wybuchowego zgodnie z planem:

- Próby 1 i 2: materiał wzmocnienia stanowił drut ze stopu kanthal (68\% Fe; $24 \% \mathrm{Cr} ; 1 \% \mathrm{Co}$ ) o średnicy $0,2 \mathrm{~mm}\left(\mathrm{R}_{\mathrm{m}}=650 \div 860 \mathrm{MPa}\right)$ ułożony prostopadle do fali detonacyjnej.

- Próba 3: materiał wzmocnienia stanowił drut ze stopu kanthal o średnicy $0,2 \mathrm{~mm}$ w postaci siatki o wymiarach oczek $1 \times 1 \mathrm{~mm}$.

- Próba 4: materiał wzmocnienia stanowił drut spawalniczy Messer-Griesheim Grini 10 (37\% Ni; 29\% Cr; 25,5\% Fe; 3,5\% Mo; 2,5\% Mn; $2 \% \mathrm{Cu} ; 0,5 \%$ $\mathrm{Si} ; 0,025 \% \mathrm{C})$ o średnicy $1,2 \mathrm{~mm}\left(\mathrm{R}_{\mathrm{m}}=820 \mathrm{MPa}\right)$ ułożony prostopadle do fali detonacyjnej.

We wszystkich przypadkach osnowę kompozytu stanowiła blacha $z$ aluminium $A 1\left(R_{m}=70 \div 110 \mathrm{MPa}\right)$ o grubości $2 \mathrm{~mm}$ i wymiarach $300 \times 300 \mathrm{~mm}$.

Wszystkie próby zgrzewania przeprowadzono w układzie równoległym $w$ ten sposób, że na masywnym podłożu stalowym układano kolejno płytę aluminiową - podstawową, a następnie w odległości $h_{1}=1 \mathrm{~mm}$ wzmocnienie oraz $\mathrm{w}$ odległości $h_{2}=1 \mathrm{~mm}$ aluminiową płytę nastrzeliwaną $\left(h_{1}+h_{2} \leq 2 \mathrm{~mm}\right)$ (rys. 2).

Powierzchnie płyt $z$ aluminium trawiono, a powierzchnie drutów i siatek oczyszczono papierem ściernym i odtłuszczono benzyną ekstrakcyjną. $\mathrm{Na}$ powierzchni płyty nastrzeliwanej umieszczono pojemniki wypełnione materiałem wybuchowym. Zastosowano materiały wybuchowe na bazie saletry amonowej: amonal $6\left(D=1800 \mathrm{~m} / \mathrm{s}, \rho_{\mathrm{w}}=0,87 \mathrm{~g} / \mathrm{cm}^{3}\right)$ dla płyt $1 \div 3$ i MS $\left(D=2200 \mathrm{~m} / \mathrm{s}, \rho_{w}=0,75 \mathrm{~g} / \mathrm{cm}^{3}\right)$ dla płyty 4. Dla materiałów tych dobrano parametry zgrzewania zapewniające uzyskanie kątów zderzenia płyt aluminiowych $\beta=19^{\circ} 20^{\prime \prime}$. Zgrzane płyty poddano badaniom wizualnym, statycznej próbie rozciągania oraz badaniom metalograficznym.

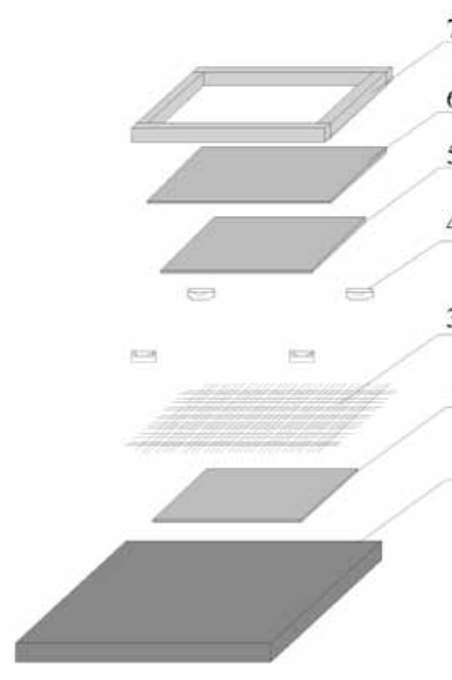
Rys. 2. Schemat układu zgrzewania kompozytu metalowego; 1 - podłoże stalowe, 2 - płyta podstawowa, 3 - wzmocnienie, 4 - kołki dystansowe, 5 - płyta nastrzeliwana, 6 - płyta bufo-

2 rowa, 7 - pojemnik na materiał wybuchowy [8]

Fig. 2. Scheme of the metal composite explosion welding. 1 - the steel anvil, 2 - the base plate, 3 - the strengthening, 4 - spacer pins, 5 - the flyer, 6 - the buffering plate, 7 - the container for explosive material 


\section{Wyniki badań}

\section{Badania wizualne}

Wszystkie płyty próbne poddano badaniom wizualnym zgodnie z wymaganiami normy [11], których wyniki zestawiono w tablicy.

Tablica. Wyniki badań wizualnych płyt próbnych Table. Results of the visual examination of test plates

\begin{tabular}{|c|l|l|}
\hline $\begin{array}{c}\text { Nr } \\
\text { płyty }\end{array}$ & \multicolumn{1}{|c|}{$\begin{array}{c}\text { Postać } \\
\text { wzmocnienia }\end{array}$} & \multicolumn{1}{c|}{ Opis i uwagi } \\
\hline 1 & Drut kanthal & $\begin{array}{l}\text { Powierzchnia kompozytu lekko wygięta, } \\
\text { brak pęknięć. Płyta buforowa pęknięta. }\end{array}$ \\
\hline 2 & Drut kanthal & $\begin{array}{l}\text { Powierzchnia kompozytu lekko wygięta, } \\
\text { brak pęknięć. Płyta buforowa pęknięta, lecz } \\
\text { W mniejszym stopniu niż płyta 1. }\end{array}$ \\
\hline 3 & $\begin{array}{l}\text { Siatka z drutu } \\
\text { kanthal }\end{array}$ & $\begin{array}{l}\text { Powierzchnia kompozytu bez niezgodności. } \\
\text { Płyta buforowa uległa całkowitemu znisz- } \\
\text { czeniu. }\end{array}$ \\
\hline 4 & $\begin{array}{l}\text { Drut Messer- } \\
\text {-Griesheim } \\
\text { Grini 10 }\end{array}$ & $\begin{array}{l}\text { Powierzchnia kompozytu bez niezgodności. } \\
\text { Płyta buforowa uległa deformacji. Widoczne } \\
\text { ułożenie wzmocnienia w kompozycie. }\end{array}$ \\
\hline
\end{tabular}

\section{Statyczna próba rozciągania}

W celu sprawdzenia prawidłowego połączenia między osnową a zbrojeniem na całej powierzchni badanego kompozytu do statycznej próby rozciągania metali próbki pobierano z różnych części płyt [12].

W przypadku kompozytów zbrojonych drutami wyniki próby rozciągania można porównać z teoretyczną wytrzymałością kompozytu obliczoną na podstawie prawa mieszanin $[5,6]$. Prawo to opisane jest równaniem:

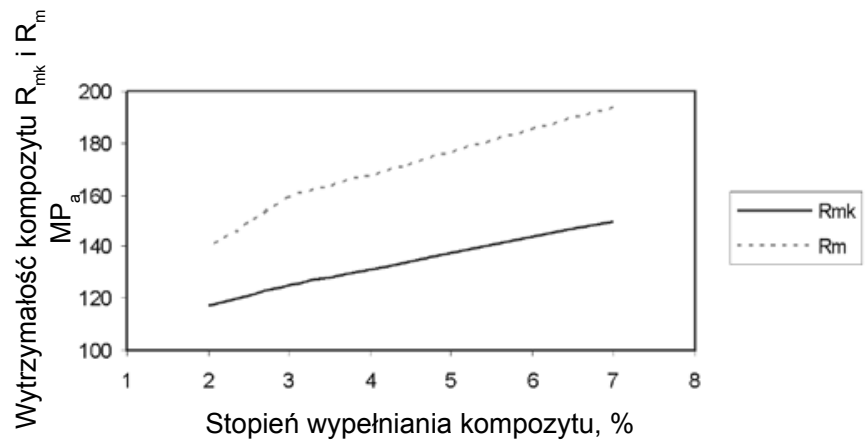

Rys. 3. Zależność między wytrzymałością rozciąganie kompozytu a stopniem wypełnienia kompozytu. $R_{m k}$ - wytrzymałość na rozciąganie obliczona z prawa mieszanin, $R_{m}$ - wytrzymałość określona w statycznej próbie rozciagania

Fig. 3. The relationship between the strength of the composite and the filling ratio of the composite. $R_{m k}$ - ultimate strength calculated from the law of mixtures, $R_{m}$ - experimental ultimate strength

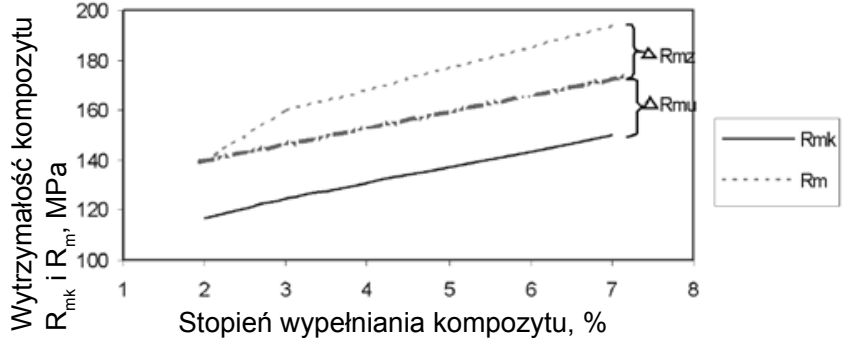

Rys. 4. Wykres przedstawiający związki między wytrzymałością kompozytu $\left(R_{m} i R_{m k}\right)$ a stopniem wypełnienia, przyrostem wytrzymałości od umocnienia płyt $\Delta \mathrm{R}_{\mathrm{mu}}$ oraz przyrostem wytrzymałości związanym z tworzeniem się na granicy faz związków międzymetalicznych $\Delta \mathrm{R}_{\mathrm{mz}}$.

Fig. 4. Graph showing the relationship between the strength of the composite $\left(R_{m}\right.$ and $\left.R_{m k}\right)$ and the filling ratio of the composite, the increase of the strength from the strengthening of plates $\Delta R_{\mathrm{mu}}$ and the increase of the strength associated with the formation of interfacial intermetallic compounds $\Delta \mathrm{R}_{\mathrm{mz}}$

$$
\mathrm{R}_{\mathrm{mk}}=\mathrm{R}_{\mathrm{mw}} \times \mathrm{V}_{\mathrm{w}}+\mathrm{R}_{\mathrm{mo}}
$$

gdzie: $R_{m k}$ - wytrzymałość na rozciąganie kompozytu, MPa; $R_{m w}$ - wytrzymałość na rozciąganie wzmocnienia, $M P a ; V_{w}$ - stosunek pola przekroju wzmocnienia do pola przekroju osnowy tzw. stopień wypełnienia; $\mathrm{R}_{\mathrm{mo}}$ - wytrzymałość na rozciąganie osnowy, MPa.

Wyniki badań i obliczeń w zależności od stopnia wypełnienia kompozytu przedstawiono na rysunku 3. Otrzymane wyniki potwierdzają doniesienia literaturowe, że wytrzymałość kompozytu zależy od stopnia wypełnienia $[4,5]$. Z wykresu wynika ponadto, że wpływ na wytrzymałość kompozytów mają również inne czynniki, ponieważ wytrzymałość określona eksperymentalnie jest wyższa się od wynikającej z prawa mieszanin. Spowodowane jest to umocnieniem wskutek zgniotu zgrzewanych płyt i prawdopodobnie powstawaniem na granicy połączeń faz związków międzymetalicznych żelazo-aluminium $\left(\mathrm{Fe}_{\mathrm{m}} \mathrm{Al}_{\mathrm{n}}\right)$. Zależności przedstawiono na rysunku 4.

\section{Badania metalograficzne}

Badania metalograficzne miały na celu stwierdzenie, czy uzyskano połączenie zadowalającej jakości pomiędzy osnową a drutami zbrojenia oraz pomiędzy płytami osnowy, poznanie budowy połączeń i wykrycie ewentualnych niezgodności. Badania przeprowadzono zgodnie z wytycznymi normy [13]. Wybrane fotografie zgładów metalograficz-

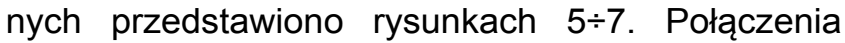
stal-aluminium we wszystkich przypadkach charakteryzują się podobną budową. Stwierdzono właściwe połączenie na całych obwodach w badanych przekrojach drutów wzmocnienia oraz pomiędzy płytami, brak deformacji drutów, a także obecność 


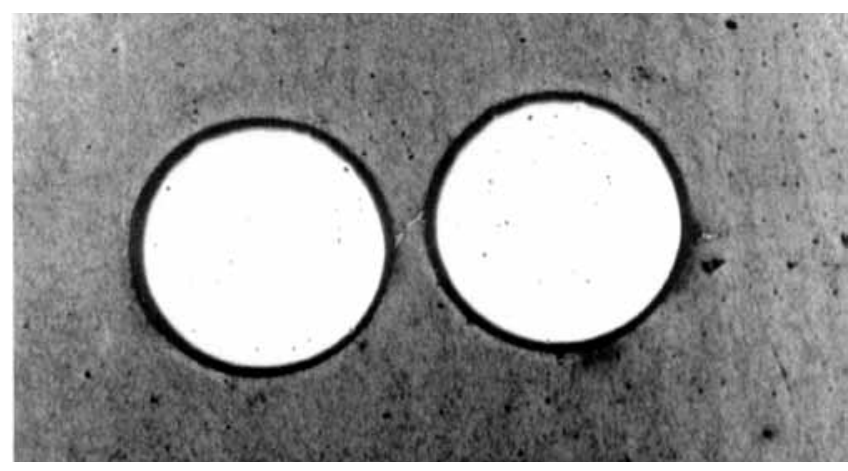

Rys. 5. Fotografia zgładu makroskopowego połączenia drut spawalniczy/aluminium w przekroju poprzecznym. Widoczne połączenie wzmocnienia z osnową poprzez warstwę związków międzymetalicznych żelazo-aluminium. Próbka nietrawiona. Pow. 32× [7]

Fig. 5. Microscopy image of cross-sections with joint: welding wire/ aluminum in cross section. Visible connection between matrix and strengthening by the layer of Intermetallic iron- aluminium compounds. Sample unetched. Magn. $32 \times$

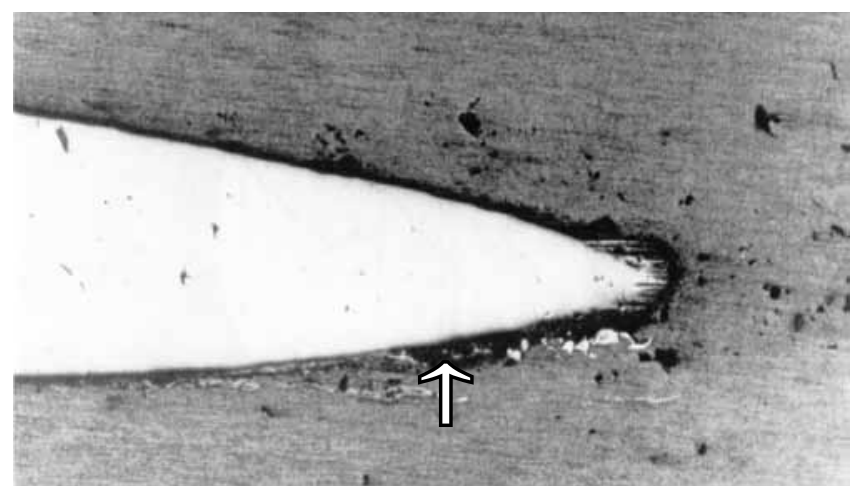

Rys. 6. Fotografia zgładu makroskopowego połączenia drut spawalniczy/aluminium w przekroju wzdłużnym. Widoczne połączenie wzmocnienia z osnową. Połączenie na całej powierzchni wzmocnienia. W miejscu wskazanym strzałką widoczna warstwa przejściowa. Próbka nietrawiona. Pow. 63× [7]

Fig. 6. Microscopy image of cross-sections with joint welding wire/ aluminum in longitudinal section. Visible connection between matrix and strengthening. The connection occurs over the entire surface of the strengthening. In the place indicated by the arrow the transition layer is visible. Sample unetched. Magn. 63x

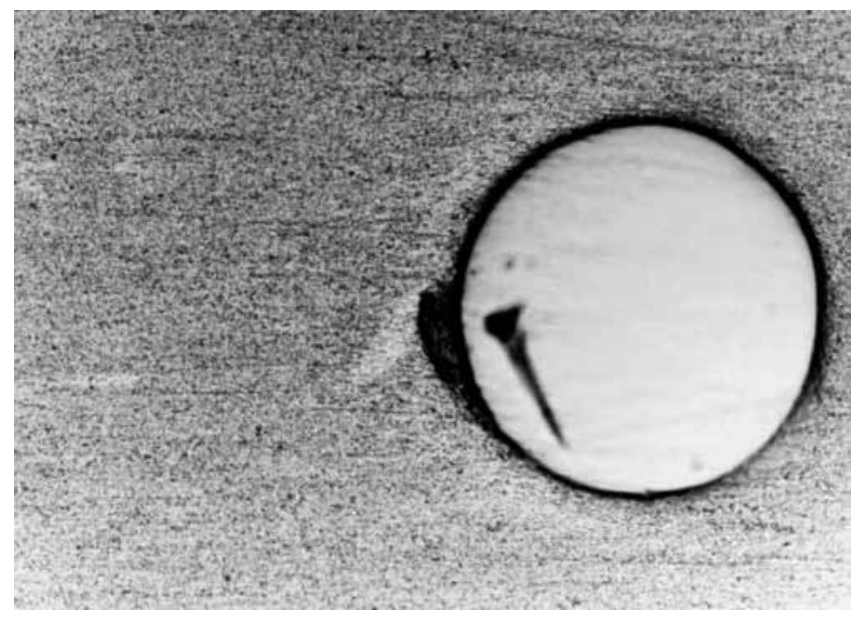

Rys. 7. Fotografia zgładu makroskopowego połączenia drut kanthal/ aluminium. Widoczne połączenie na całym obwodzie wzmocnienia. Drut nie uległ deformacji. Pow. 200× [8]

Fig. 7. Microscopy image of cross-sections with joint kanthal wire/ aluminum. The connection occurs over the entire circumference of the strengthening. No deformation in wire occurred. Sample unetched. Magn. 200x warstwy związków międzymetalicznych. Niezgodności typowych dla złączy zgrzewanych wybuchowo nie wykryto.

\section{Podsumowanie}

Kompozyty metalowe nie należą dotychczas do materiałów powszechnie dostępnych i szeroko stosowanych. Szersze zastosowanie kompozytów tego typu uzyskiwanych za pomocą zgrzewania wybuchowego wymaga przeprowadzenia systematycznych badań nad możliwościami ich wytwarzania i właściwościami złączy. W artykule przedstawiono wyniki prac o charakterze rozpoznawczym, lecz składających się na kompletny cykl obejmujący opracowanie technologii zgrzewania wybuchowego, badania wizualne i metalograficzne makroskopowe oraz analityczne i eksperymentalne wyznaczenie wytrzymałości na rozciąganie. Otrzymane wyniki upoważniają do stwierdzenia, że zgrzewanie wybuchowe umożliwia uzyskanie trwałego połączenia pomiędzy aluminiową osnową a stalowym wzmocnieniem kompozytu metalowego o wytrzymałości będącej sumą wytrzymałości wynikającej z prawa mieszanin oraz wzrostu wytrzymałości wynikającej z dwóch dodatkowych mechanizmów: umocnienia materiału wskutek zgniotu oraz formowania się związków międzymetalicznych.

Zaprezentowane wyniki badań wstępnych dają możliwość wytyczenia kierunków dalszych badań mogących doprowadzić do opracowania kompletnej przemysłowej technologii wytwarzania kompozytu $z$ aluminium wzmocnionego drutami stalowymi. Badania można kontynuować w kierunkach: doboru odpowiedniego stopnia wypełnienia kompozytu wzmocnieniem (zmiany układu, ilości i średnicy drutów), doboru składu chemicznego i właściwości wytrzymałościowych drutów, czy opracowania technologii zgrzewania kompozytów wielowarstwowych o żądanych właściwościach.

\section{Wnioski}

Opracowano technologię zgrzewania wybuchowego kompozytów metalowych $z$ aluminiową osnową i stalowym wzmocnieniem w postaci drutu lub siatki.

Zgrzewanie wybuchowe umożliwia uzyskanie trwałego połączenia pomiędzy aluminiową osnową a stalowym wzmocnieniem kompozytu metalowego.

Wytrzymałość na rozciąganie kompozytów przewyższa wytrzymałość teoretyczną wynikającą z prawa mieszanin. 


\title{
Literatura
}

[1] Babul W.: Odkształcanie metali wybuchem. WNT, Warszawa 1980.

[2] Dieribas A.A.: Fizika uprocznienija i swarki wzrywom. Nauka, Nowosibirsk 1980.

[3] Hokamoto K., Chiba A., Fujita M., Izuma T.: Single-shot weIding technique for the fabrication of multilayered metal base composites: effect of welding parameters leading to optimum bonding condition. Composites Engineering, vol. 5, no. 8, s. 1069-1079, 1995.

[4] Kapuściński J., Puciłowski K., Wojciechowski S.: Kompozyty - podstawy projektowania i wytwarzania. Oficyna Wydawnicza PW. Warszawa 1993.

[5] Karpinos D.M. i inni.: Procznost kompoziycionnych materiałow. Nauka Dumka, Kijew 1978.

[6] Nishida M., Minakuchi K., Anado K., and Araki T., Hyodo K.: Fabrication of high-strength steel fiber reinforced metal matrix composites by explosive bonding and their tensile properties. Welding International, vol. 9, iss. 3, January 1995, s. $179-184$
[7] Rogalski G.: Badania właściwości kompozytu drut stalowy plus aluminium zgrzewanego wybuchowo. Praca dyplomowa inżynierska. Gdańsk 1998.

[8] Rogalski G.: Technologia zgrzewania i właściwości płyt $z$ aluminium i stopów zbrojonych drutami stalowymi. Praca dyplomowa magisterska. Gdańsk 2000.

[9] Śleziona J.: Podstawy technologii kompozytu. Wydawnictwo Politechniki Śląskiej. Gliwice 1998.

[10] Walczak W.: Zgrzewanie wybuchowe metali i jego zastosowanie. WNT, Warszawa 1989.

[11] PN-EN ISO 17637:2011 Badania nieniszczące złączy spawanych. Badania wizualne złączy spawanych.

[12] PN-EN ISO 6892-1:2010P Metale. Próba rozciągania -Czéść 1: Metoda badania w temperaturze pokojowej.

[13] PN-EN 1321:2000 Spawalnictwo. Badania niszczące metalowych złączy spawanych. Badania makroskopowe i mikroskopowe złączy spawanych.

Niniejszy artykuł jest rezultatem prac prowadzonych przez Prof. dr hab. inż. Włodzimierza Walczaka ze swoimi dyplomantami, a późniejszymi doktorantami i współ-pracownikami. Geneza prezentowanych wyników badań związana jest z praktycznymi aspektami głównego nurtu szkoły naukowej Profesora, zgrzewania wybuchowego.
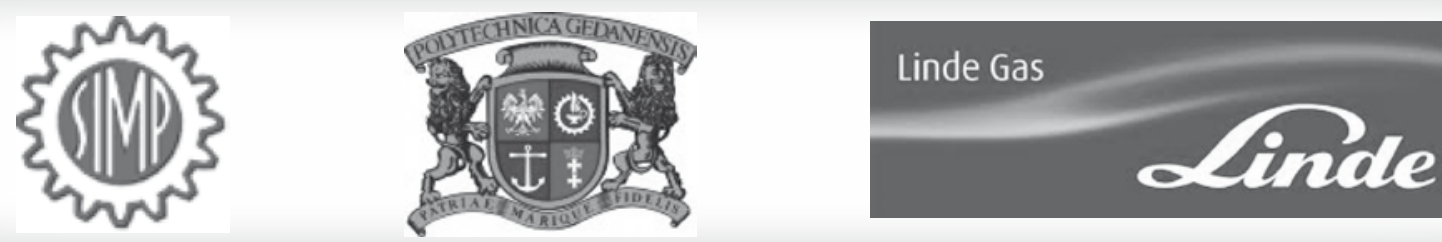

Mamy przyjemność zaprosić Państwa do uczestnictwa w:

\section{NAUKOWO-TECHNICZNEJ KONFERENCJI SPAWALNICZEJ pod hasłem: \\ SPAWALNICTWO W TRZECH ŻYWIOŁACH: ZIEMIA - WODA - POWIETRZE}

\author{
organizowanej w dniach 14-16 października 2013 r. w Gdańsku-Sobieszewie przez:
}

\section{Zakład Inżynierii Spajania Politechniki Gdańskiej, SIMP Oddział w Gdańsku, Linde Gaz Polska}

Konferencja odbędzie się w Ośrodku Wypoczynkowym „Orle” położonym na Wyspie Sobieszewskiej niedaleko ujścia Wisły do Zatoki Gdańskiej. W czasie konferencji przedstawione zostaną najnowsze osiągnięcia naukowe i techniczne z zakresu spawalnictwa. W programie konferencji przewidziane są również wycieczki techniczne oraz warsztaty.

dr hab. inż. Jerzy Łabanowski:

dr inż. Dariusz Fydrych:
Bliższych informacji udzielają:

tel.: 583472366 ;

jlabanow@pg.gda.pl

tel.: 583486321 ;

dfydrych@mech.pg.gda.pl

Politechnika Gdańska, Wydział Mechaniczny, Zakład Inżynierii Spajania,

ul. Narutowicza 11/12, 80-233 Gdańsk, http://www.konferencjaspawalnicza.pl/ 